\title{
DELUSION IN THE COURTROOM: THE ROLE OF PARTIAL INSANITY IN EARLY FORENSIC TESTIMONY
}

\author{
by
}

\author{
JOEL PETER EIGEN *
}

Standing in the dock at the Old Bailey in 1833, Noah Pease Folger, Captain of the Sophia, seemed the soul of propriety. "No man was more kind hearted and human ...", testified another ship's captain, who saw Folger three weeks before he attempted to kill Mr Mellish, the owner of the Sophia. Certainly "kind hearted and human" persons, if brought to the point of rage, had been known to commit acts of the most inhuman barbarity, yet Folger evinced a singular sort of distraction. His disorder, the jury was told, only began "when the subject which caused his malady was raised . . . he was quite calm and collected till Mr. Mellish's name came into question". In his moments of deep derangement, the Captain of the Sophia had been known to break window panes with his bare fists, dance on the broken glass, strip naked, and complete the episode by jumping on the back of a passing whale. With such a vividly illustrated history of madness, why should there have been any question regarding his plea of insanity?

Although the captain's antics may strike the twentieth-century reader as persuasive grounds for a defence of insanity, the legal stricture of total madness as the criterion for an acquittal meant that it was actually the captain's rational moments which were on trial; for example, his confession immediately following arrest-“"I shot him, I know the laws of my country and I shall be hung for it". Jurors also heard reports of the captain's self-composure when he forgot about the torments he attributed to his nemesis. Without a conception of the mind which allowed for the possibility of limited, circumscribed seats of madness, the captain's equanimity on his smooth-sailing days might well have militated against an acquittal. How was the jury in the Folger case, and in similar trials heard in London in the second quarter of the nineteenth century, brought to an understanding of the possibility of hidden madness in the mind of an otherwise reasonable person?

Contemporary efforts to capture how inhabitants of earlier historical periods conceived of the mind of the mad have drawn on a variety of sources, and include scholarly investigations of the history of ideas and thought systems, medical tracts published by madhouse keepers and mad-doctors, and in a few instances, memoirs of recovered melancholics. Of continuing interest in this historical endeavour has been the effort to discern fundamental shifts and refinements in the conceptualization of

* Joel Peter Eigen, Ph.D., Department of Sociology, Franklin and Marshall College, Lancaster, PA 17604, USA. 
how the mad differed from the sane. One such historical shift, traceable in both clinical and medical writings, was the transition from total to partial insanity. The various conceptual manoeuvres used to effect the acceptance of partial insanity-lucid intervals, délire partiel, monomania - have been explored in the medical and scholarly literature. The present paper aims to describe the diffusion of clinical and psychological notions of partial insanity into the critical arena of the criminal trial, a forum which for centuries had witnessed the rejection of partial states of derangement as grounds for an acquittal.

What follows is an analysis of medical testimony offered in insanity trials in London between the years 1825 and 1843, the period which witnessed a six-fold increase in the participation of medical witnesses at the Old Bailey, ${ }^{1}$ and which culminated in the formation of the Insanity Rules during the trial of Daniel McNaughtan. Because criminal responsibility traditionally rested with the actor's capacity to understand the nature of his actions and the consequences such actions would likely bring, medical testimony regarding the mental state of the accused provides a compelling glimpse into the introduction and application of clinical conceptions of partial insanity to traditional legal notions of criminal responsibility. Particularly valuable are the voices of medical witnesses who endeavoured to work changing perceptions of mental derangement into a rendering of the mind of the prisoner which the legal community would find difficult to dismiss. By analysing medical as well as lay testimony over time, today's historian of forensic psychiatry can also investigate how contemporary social actors understood the functioning of the mind, the integration of various faculties, and the acceptance of an insanity that was confined to an idea or a limited number of subjects. The fit of partial insanity, represented most often by the term "delusion", accompanied by the criminal activity exemplified by the hapless, whale-jumping Captain of the Sophia, is the subject of this paper.

\section{PARTIAL INSANITY IN LEGAL CONTEXT}

At the heart of the legal concept of criminal responsibility lies the defendant's intention. ${ }^{2}$ If guilt arose only in the commission of an act, the effort to reconstruct the mental state of the offender at the time of the crime would matter little, if at all. A legal system based on strict liability-which appears to have been in force in England before the Middle Ages-would be solely concerned with determining the cause of death and identifying the responsible party. ${ }^{3}$ By the twelfth century, the nature of criminal

\footnotetext{
${ }^{1}$ Joel P. Eigen and Gregory Andoll, 'From mad-doctor to forensic witness: the evolution of early English court psychiatry', Int. J. Law Psychiat., 1986, 9: 159-69.

2 For discussions of intention, criminal responsibility, and the common law, see Glanville Williams, Criminal law, the general part, 2nd ed., London, Stevens \& Sons, 1961, pp. 30-53; James Fitzjames Stephen, $A$ history of the criminal law of England, vol. 2, London, Macmillan, 1883, pp. 94-114, 124-86; Roger Smith, Trial by medicine: insanity and responsibility in Victorian trials, Edinburgh University Press, 1981, pp. 67-96. The most complete analysis of the historical evolution of legal thinking on madness and responsibility may be found in Nigel D. Walker, Crime and insanity in England, vol. 1, The historical perspective, Edinburgh University Press, 1968. Further investigation of courtroom applications of intentionality and insanity is offered in Joel P. Eigen, 'Intentionality and insanity; what the eighteenthcentury juror heard', in W. F. Bynum, R. Porter, and M. Shepherd (eds.) The anatomy of madness, vol. 2, Institutions and society, London, Tavistock, 1985, pp. 34-51.

${ }^{3}$ Walker, op. cit., note 2 above.
} 


\section{Partial insanity in early forensic testimony}

responsibility grew more problematic as for the first time, a mention of the mental element became necessary for the fixing of guilt: the will to harm. Only the actor whose state of mind permitted an understanding of the (moral) wrongfulness of his behaviour and who retained the capacity not to choose a course of action, could be said to have acted intentionally; with the will to harm.

The capacity to understand the events surrounding one's course of action, however, is not an "either-or" faculty. While some people, idiots for example, were clearly beyond any rationality, other persons appeared deranged "by degrees". The cultural and medical acknowledgement of a range of pathological mental states challenged jurists to formulate a standard as to the requisite level of impairment which would merit a defence against punishment (initially), and conviction (eventually). Legal tracts written by Sir Matthew Hale and Lord Coke, together with judicial instructions dating to the late eighteenth century, reveal that juries were traditionally instructed that only a total want of memory and understanding - a total insanity - would satisfy the law's criterion for exemption from culpability. Partial states of madness, melancholy for example, in which individuals retained the level of understanding that a youth of 14 might be expected to possess, left the partially deranged answerable for their conduct because they were deemed capable of distinguishing right from wrong. ${ }^{4}$

By the late eighteenth and early nineteenth century, terms such as melancholy, mania, and delirium, indeed the entire conceptualization of insanity in strictly "intellectualist" terms, were the subject of clinical and philosophical revaluation and subsequently, reclassification. The claims of various schools-associationism, phrenology, "Common Sense" philosophy-to explain the mind's capacity to understand and to reason, begged the traditional legal categories of total and partial insanity. Although judges continued to employ such criteria as "knowing right from wrong" and "knowing what one was about" in their instructions to the jury, medical testimony in the second quarter of the nineteenth century argued persuasively that defendants who generally knew the difference between right and wrong could nonetheless be either incapable of understanding the blameworthiness of a particular action, or unable to resist the force of a preoccupying passion. In short, medical witnesses employed language and images which challenged the jurors to question the existence of a mind integrated in its faculties and consistent in its consciousness.

\section{SOURCE OF DATA AND OVER VIEW OF PREVIOUS FINDINGS}

Although criminal trials were not the only legal forum in which mental states were of critical significance-coroners' inquests and lunacy commissions often witnessed testimony about severe derangement ${ }^{5}$ - few tribunals constituted as public an event as a felony prosecution. Not only were criminal trials themselves matters of great public interest; reports of prosecutions were also the subjects of seemingly unlimited curiosity within English society. From the Elizabethan era on, pamphlets known as crime chap-books provided lurid and sensational descriptions of criminal trials and

\footnotetext{
${ }^{4}$ Matthew Hale, The history of the pleas of the crown, London, E. R. Nutt, 1736, pp. 30-7.

${ }^{5}$ Michael MacDonald, 'Insanity and the realities of history in early modern England', Psych. Med., 1981, 11: 25. See also MacDonald's 'The inner side of wisdom: suicide in early modern England', ibid., 1977, 7: 565-82, and 'The secularisation of suicide in England 1600-1800', Past and Present, 1986, 111: 50-97.
} 
subsequent sentencing. Written by non-lawyers for sale to the general public, they offered the London populace "freshly committed, freshly prosecuted crimes". 6 Beginning in 1674, a new source of trial reports, the Old Bailey Sessions Papers (hereafter $O B S P$ ) provided testimony given at London's Central Criminal Court, the Old Bailey. In 1775 the Common Council for the City of London ordered the publishing of the papers, thus institutionalizing a practice already begun by "enterprising commercial printers" who dispatched shorthand writers to the Old Bailey to record the proceedings. ${ }^{7}$ Written neither in the language of contemporary medical treatises nor that of legal documents, these narratives offer a glimpse into the thoughts and language of the proverbial person on the (London) street. ${ }^{8}$

Earlier work examining testimony in felony prosecutions has investigated trials heard at the Old Bailey from 1760 to 1815 , and included all trials in which mental debility was raised as a possible exculpatory factor. ${ }^{9}$ The ways in which this was done could range from a prisoner's relatively casual statement - "I was out of my wits at the time"- to the formal use of medical witnesses testifying about the defendant's history of inexplicable behaviour and perhaps the presence of a mad lineage. Medical witnesses in the late 1700 s were by far the exception, appearing in no more than ten per cent of insanity trials. ${ }^{10}$ Not only was their appearance infrequent, their testimony was quite unremarkable. "I have looked upon him as a man insane" constituted a commonly heard example of "expert" testimony. When pressed for the basis of this conclusion, medical witnesses most often described the prisoner's inability to carry on a conversation, to follow a question with a logical answer. Ideas, the court and jury learned, were seldom connected in any rational way. Rather, the most often-heard descriptions of the verbal patterns of the mad were "flighty", and "inconsistent".

The imagery found in eighteenth-century medical testimony flows directly from the fundamental tenets of associationism, the dominant school of psychology in the mid-to-late 1700s. Based on the Lockean belief that all knowledge originates in sensory experience and in the subsequent patterns of thought which result from our sensations of the outside world, associationism maintained that the repetition of sensations and their resulting ideas become associated with one another and combine to form, in the vernacular, a "train of thought". It was in the train of thought that Locke initially distinguished the sane from the mad. The mad, "having joined together some ideas very wrongly . . . mistake them for Truths ... as though incoherent ideas have been cemented together so powerfully as to remain united". "By the late eighteenth century,

\footnotetext{
6 John H. Langbein, 'The criminal trial before the lawyers', Univ. Chicago Law Rev., 1978, 45: $267-72$.

7 Thomas Rogers Forbes, Surgeons at the Bailey. English forensic medicine to 1878, New Haven, Yale University Press, 1985, pp. 15-23.

${ }^{8}$ Langbein, op. cit., note 6 above, p. 271. The author scrutinized the historical credibility of the $O B S P$ by employing the shorthand trial notes of Judge Dudley Ryder, who presided during the 1760s. When the judge's notes have been set against the trial narratives, the papers have been deemed reliable. See Langbein's 'Shaping the eighteenth-century criminal trial, a view from the Ryder sources', Univ. Chicago Law Rev., 1983, 50: 1-16.

${ }^{9}$ Eigen, op. cit., note 2 above.

10 Ibid.

11 John Locke, An essay concerning human understanding (1690), ed. John Yolton, London, Everyman, 1961. For an expanded discussion of associationism, see Robert Hoeldtke, 'The history of associationism and British medical psychology', Med. Hist., 1967, 11: 45-65.
} 
insanity had come to be identified with abnormal patterns in the association of ideas which profoundly disturbed the individual's judgement. These abnormal patterns were traceable, theoretically, to anatomical defects in sensation. ${ }^{12}$

A physiological grounding for associationism was not imparted to the jury. Rather, purely mentalist notions of a random disorder in the train of thought, conveyed by the terms "flighty" and "incoherent", were proffered by medical witnesses who perhaps had little interest (or knowledge) in the more "academical" conceptions of the mind. ${ }^{13}$ Indeed, their testimony referred predominantly to common-sense expectations that ideas expressed in seriatim should bear some relation to one another, that an answer given by the prisoner should bear some relation to the question asked. Clearly, it required no medical training to interpret an answer as incoherent, or a general conversation as flighty. Neighbours, lovers, and relatives were perfectly well positioned to hear and recount examples of delirious speech. Further, lay witnesses also had the advantage of supplementing an example of flighty conversation with knowledge of the accused's history of bizarre behaviour; baying at the moon, uncontrollable laughter, a penchant for running naked through the streets holding lighted candles. As Roy Porter has written, the lunacy of an eighteenthcentury mad person was spectacularly on view. Madness was unmistakable; doubts about the reliability of "Nature's legibility" troubled few. ${ }^{14}$

By the second quarter of the nineteenth century, however, trial testimony reveals a noticeable refinement in medical conceptions of how the mad differed from the sane. Incoherent or flighty conversation gave way, as the most frequently invoked sign of madness, to a symptom category which, although ubiquitous in the history of Western thought, only entered the English criminal trial after 1800 . When Thomas Erskine introduced the concept of "delusion" into English criminal jurisprudence during the trial of James Hadfield, few court bystanders could have foretold that a quarter of a century later, it would become the term most frequently invoked to characterize the mind of the mad. Half of the medical witnesses who appeared at the Old Bailey in the second quarter of the nineteenth century to speak in support of the prisoner's plea of insanity employed the idea of delusion or monomania when they provided a description of the defendants' mental functioning. While lay witnesses continued to dwell on manifestly legible and audible signs of madness-rambling conversation, histrionic antics, uncontrollable laughter-medical witnesses introduced a form of insanity no longer on view to the casual observer. Its very "reasoning quality" had to be probed and scrutinized over time to determine the extent of derangement that attended delusion.

From a tradition of relying upon bizarre behaviour or incoherent conversation to define the boundary between reason and madness, the third and fourth decade of the nineteenth century witnessed the increasing use of the content of delusions to demarcate the limits between eccentricity and insanity. Further, where eighteenth-

\footnotetext{
12 David Hartley, Observations on man, his frame, his duty, and his expectations, London, S. Richardson, 1749.

${ }^{13}$ See, for example, Dr Reynolds's testimony, OBSP, 1784, Eighth Session, p. 1301.

${ }^{14}$ Roy Porter, Mind-forg'd manacles: the history of madness in England from the Restoration to the Regency, Cambridge, Harvard University Press, and London, Athlone Press, 1987, p. 35.
} 
century medical men had eschewed discussions of the afflicted's thought-world for fear it would only reify his mis-association of ideas, ${ }^{15}$ medical witnesses in the second quarter of the nineteenth century introduced graphically-illustrated delusions directly into their testimony to illustrate the sway of a reasoning mania. This was a decidedly new form of insanity: not mad in the traditional sense of "irrationality", but irresponsible due to a fateful error in belief. Was it perhaps the very intelligibility of the prisoner's derangement that led the jurors to acquit?

\section{DELUSION, MELANCHOLIA, AND PARTIAL INSANITY}

Medical philosophers and practitioners since antiquity have commented upon partial forms of derangement which could exist side-by-side with the afflicted's sane understanding in all other matters. Care must be taken in transporting the modern meaning of "delusion" through centuries of Western experience because the mental state described by this term ranged from a misperception of sensory input-i.e., illusions or hallucinations - to the misconstruing of an event or notion, and the subsequent preoccupation with that idea. Although the precise form that derangement may have taken varied, delusion's presence in ancient, Arabic, medieval, Renaissance, and early modern European medical writings attests to the historical familiarity of partial states of derangement, as distinct from all-encompassing mania. ${ }^{16}$ Melancholia was considered by the Greeks to be just such a state, and it was in the melancholic's prophecies that Aristotle first located the presence of delusion. The association of delusive fear with melancholia - often concerning abandonment by God-was to continue throughout the Middle Ages and into early modern Europe. In the seventeenth century, Robert Burton grouped together religious delusions, idiosyncratic religious beliefs, and obsessive religious anxieties into his category, "religious melancholia". ${ }^{17}$ As often as religious fears and other threatening preoccupations were recounted and became part of popular lore,$^{18}$ it is important to stress that such beliefs did not constitute a separate psychopathological entity. It was within the domain of melancholia that delusion found its home.

Delusion also began to find a home in non-criminal legal proceedings in the early decades of the eighteenth century. Lunacy hearings held in the Courts of Chancery, for example, featured testimony about the "wild fancies" of suspected madmen. ${ }^{19}$ From an initial reliance on the stereotypical behaviour of the wild distracted madman, the educated élite of late seventeenth- and early eighteenth-century England began to base their inference of madness on the ideas of the madman. Ideas of possession and demonic influence were therefore secularized-one might say medicalized -in that fear of possession came to be taken as a sign of an insane delusion, rather than the grounds to suspect a pact with the Evil One. Evidence of lay

\footnotetext{
15 Ibid., p. 281.

${ }^{16}$ Stanley W. Jackson, Melancholia and depression: from Hippocratic times to modern times, New Haven, Yale University Press, 1968.

${ }_{17}$ Robert Burton, The anatomy of melancholy, vol. 3, New York, Hurd \& Houghton, 1864, pp. 365-501.

18 Jackson, op. cit., note 16 above, pp. 31-3.

${ }^{19}$ MacDonald, 'Insanity and realities' and 'The secularisation', op. cit., note 5 above.
} 
concurrence in the medical interpretation of lunacy can also be found in the profusion of findings of non compos mentis recorded in suicide hearings in the late seventeenth century. ${ }^{20}$

The focus on ideas and beliefs of the madman serves to underscore the eighteenth century's predominant conception of insanity as one of intellectual, as distinct from emotional, disturbance. Regardless of the frequency with which delusion appears in the medical literature as a characterization of the mind of the mad, it should be stressed that "delirium" remained the stable mental category throughout the late 1700s. Delirium, which traditionally referred to behavioural and mental symptoms occurring in the wake of physical disease, ${ }^{21}$ encompassed both a general state of confusion, as well as specific errors in belief. To account for the organic basis of such profound confusion, medical writers in the mid-to-late 1700 s followed the general outline of David Hartley's psycho-physiological rendering of the link between mental derangement and organic pathology in the faulty mechanism of vibration and sensation, resulting in the delirium of misassociated ideas. Some disturbance, some irritation in nerve endings relaying raw sensory input to the brain, impaired the mind's capacity to consider and compare incoming ideas with those already present.

Medical texts published in the second half of the eighteenth century reveal a range of opinions regarding the precise nature of madness, and the possibility that mental disturbance could be limited to one subject. In 1758, William Battie characterized madness as deluded imagination, restricting the concept of delusion to an irritation in sensory input. ${ }^{22}$ Battie's use of delusion resembles "ideal delirium", a classification articulated later in the century by Thomas Arnold, which signified sensory disturbance. Arnold's second category, "notional delirium", delineated a further refinement in derangement: "without the slightest distinguishable trace of ideal delirium . . . and with the sound and unimpaired use of rational faculties . . the patient in relation to some particular object . . . is under the influence of the most palpable and extraordinary delusion." 23 Arnold was not alone in the effort to

${ }^{20}$ MacDonald, 'The inner side', op. cit., note 5 above.

${ }^{21} \mathrm{G}$. E. Berrios, 'Delirium and confusion in the nineteenth century: a conceptual history', Br. J. Psychiat., 1981, 139: 439-49. See also H. Werlinder, Psychopathy: a history of the concepts, analysis of the origin and development of a family of concepts in psychopathology, Acta Universitatis Upsaliensis, Uppsala, 1978, pp. 26-8.

22 William J. Battie, A treatise on madness, London, John Clarke, 1758, pp. 5-6. Battie's apparent narrowing of madness to "deluded imagination" was forcefully rejected by John Monro. "Does the naked wanderer suffer from deluded imagination?" Those who recover, continued Monro, describe their experiences as a total suspension of every rational activity. Clearly, Monro conceived of madness in the traditional sphere of overwhelming derangement. Only a global disturbance could explain the "otherness" of the mad: the confused and incoherent speech, the flightiness of their ideas, their hallucinations and delusion. For an expanded discussion of Monro's differences with Battie, see John Monro, Remarks on Dr Battie's treatise on madness, London, John Clarke, 1758.

${ }^{23}$ The role of the senses in misleading the individual into embracing delusive notions placed some mental states into the category of "ideal insanity". Thus Arnold wrote of a learned man, who "fancied that his legs were nothing but glass, and for that reason dared on no account to venture to stand upon them". The scholar was cured by his surly parlour maid who tired of her master's insanity and "gave him a smart blow on the leg with one of the logs ... [thus provoked, he] rose from his seat in a violent hurry to revenge the insult ... happy to find that his legs would support him; and his mind was from that time perfectly freed 


\section{Joel Peter Eigen}

demarcate various states of derangement. The Birmingham physician John Johnstone employed the term "predominant idea" to distinguish madness from delirium. In madness, an all-consuming "predominant idea" interfered with, and deranged all trains of thought with which it was "intermixed". Delirium, on the other hand, was "but a wild and incoherent jumble of ideas". ${ }^{24}$ Although the inconsistent use of such key terms as "delirium" and "delusion" makes it difficult to infer the precise nature of innovative nosologies which appear in the late eighteenth century, theoretically at least, both Johnstone's conception of madness as "predominant idea", and Arnold's classification of notional delirium allowed for a conception of mental disturbance as restricted or circumscribed impairment, a condition somewhat short of global and consistent derangement.

Clearly several issues were being raised in this late eighteenth-century effort to explain exactly what madness consisted of, and whether disturbance could be limited to a particular subject. In some respects, the attempt to distinguish forms of derangement by the extent of impairment was only the latest manifestation of a historic debate regarding mania and melancholia. Was the periodic display of calm, if dolorous, demeanour, merely a temporary lapse of furious mania? Early in the nineteenth century, John Haslam addressed this classic conundrum, as well as the emerging opinion that centred derangement on a particular subject, by writing that madmen were equally deranged upon a wide variety of subjects. He vigorously denied that the mind of the delusional was "rational" on all other subjects. The apparent display of rationality was but a lucid interval. Let the conversation be protracted, let the discourse drift to "the favourite subject . . . afloat in the mad man's brain, and [the observer] will be convinced of the hastiness of his decision." 25

Haslam's forceful opinion regarding the presence of generalized delirium even in those cases where derangement appeared to be limited to a particular subject, did not inhibit other medical writers from constructing definitions of insanity that suggested a circumscribed error of judgement. George Edward Male, Haslam's contemporary and one of the founders of English medical jurisprudence, averred that insanity "may be called a delusion . . . [an] erroneous association of ideas on particular subjects."26 Although few authors went so far as Alexander Morison when he elevated delusion into the condition "sufficient to excuse the commission of a crime", 27 one discerns in the rapidly growing corpus of medical opinion in the early nineteenth century, the

from this absurd imagination". Arnold's separation of types of deliria follows his conviction that "ideal insanity" describes those perceptual errors that could be corrected by the senses; "notional insanity" is just that-notions or ideas that are not amenable to correction by the proper decoding of sensory information. For an expanded discussion of Arnold's ideas, see Thomas Arnold, Observation on the nature, kind, causes, and prevention of insanity, London, Richard Phillips, 1806.

${ }_{24}$ John Johnstone, Medical jurisprudence of madness, Birmingham, J. Belcher, 1800, p. 23.

25 John Haslam, Observations on madness and melancholy: including practical remarks on those diseases: together with cases: and an account of the morbid appearances on dissection, London, J. Callow, 1809.

${ }^{26}$ George Edward Male, Elements of juridical or forensic medicine: for the use of medical men, coroners and barristers, London, E. Cox \& Son, 1818, p. 202.

${ }^{27}$ Alexander Morison, Outlines of lectures on mental diseases, London, Longman, Rees, Orme, Brown, Green \& S. Highley, 1826. Morison clearly considered delusion to be of major legal importance; his comments do not necessarily allow the inference that medical opinion was unanimous on the centrality of delusion to madness. 
emergence and acceptance of states of madness which were distinguished from generalized delirium by their seeming confinement to a "predominant idea". Increasingly, "delusion" was employed to describe such a state.

When medical theorists narrowed their conception of madness to an erroneous association about particular subjects, they did not put forward a corresponding model of the mind which would adequately account for specificity of thought disturbance. Given Hartley's initial physiological model, which drew together a concatenation of nerve endings, tightly-packed filaments, and associated mental images, it was not at all clear how the mind could be deranged on only one particular subject or set of ideas. In contrast, the neuro-anatomist Franz Josef Gall proffered an explanation of the mind's functioning which considered the cerebral localization of psychological faculties as its fundamental principle, and explained the idiosyncrasy of character by the uneven development of innate psychological faculties situated in the brain. ${ }^{28}$

According to Gall, Locke's view of madness-disordered reason and judgementonly characterized those persons suffering a general alienation or a complete insanity. To account for derangement restricted to a particular subject, one had to seek the particularity of character to be found in any of 27 determinate faculties, each with its own organ in the brain. As these organs functioned independently of one another, the corresponding psychological faculty could be deranged in isolation. It was thus the "organ of self preservation", of "sexual gratification", or perhaps of "cunning" which was implicated in a (criminally) insane act committed by an otherwise kind and gentle person. Gall and those who adhered to his model sought an explanation for the peculiarities of thought and behaviour in the variable state of the affecting organ, be it overdeveloped, underdeveloped, or in some way damaged. ${ }^{29}$ When its unusual state was discerned-either externally (by cranial inspection), or internally (after an autopsy) -an explanation was readily apparent: the faculty was distorted because its sensory products were refracted through the medium of a damaged organ.

Although phrenology enjoyed considerable popularity in the second quarter of the nineteenth century among the general public and in scientific circles as well, it was not without its detractors. ${ }^{30}$ Gall's sterling credentials as a neuro-anatomist could only go so far; the simple truth was that he could not demonstrate the existence of his determinate organs. His psychology of particular faculties therefore shared the same shortcoming as earlier explanations which relied on innate, inductive mental capacities: circularity. Still, his public lectures and publications reached a very wide audience and offered an intriguing conception of a modular mind: one that could house partial derangement while the person appeared sane in all other faculties. ${ }^{31}$ What Gall failed to offer was an application of his phrenological principles to the

\footnotetext{
${ }^{28}$ Gall's interests in particularity led him beyond a consideration of normative faculties-will, reason, and reflection-which all members of a species share. Instead he sought to illuminate the array of determinate attributes which distinguish the character, talent, and disposition of one person from other members of the species. See Rober M. Young, Mind, brain and adaptation in the nineteenth century: cerebral localisation and its biological context from Gall to Ferrier, Oxford, Clarendon Press, 1970, pp. 9-53.

${ }_{29}$ Roger Cooter, The cultural meaning of popular science, Cambridge University Press, 1985.

30 Young, op. cit., note 28 above, p. 22. For other criticisms of Gall see Cooter, op. cit., note 29 above, pp. 22-8.

31 The Weekly Medico-Chirurgical and Philosophical Magazine, 24 May 1823, no. 16, pp. 247-50; 9 August, no. 27, pp. 18-21. For a discussion of the different faculty psychology approaches to the mind, see Jerry A. Fodor, The modularity of mind: an essay on faculty psychology, Cambridge, Mass., MIT Press, 1983.
} 
terminology of medico-legal jurisprudence-partial insanity, melancholia, delirium -or a persuasive rationale to justify exempting from criminal responsibility a person with an enlarged "organ of self-protection". 32

The first sustained attempt to apply the notion of a limited, circumscribed derangement to the legal implications of the partial insanity concept was assayed by the French school of médecin mentale headed by Philippe Pinel, J. E. D. Esquirol, and Etienne Georget. Their interest in délire partiel was intrinsic to a fundamental questioning of mental derangement as primarily a matter of intellectual disturbance. As late as 1816, William Cullen had defined partial insanity as "a false and mistaken judgment upon one particular subject, and what relates to it; whilst, on every other subject, the person affected judges as the generality of other men do". 33 His conception of partial insanity reveals the enduring view of derangement as an intellectual defect: insanity as delirium. Against this long-held tradition, Pinel asserted the existence of manie sans délire, a mental disorder without reasoning defect, delusion, or hallucination. Instead, the afflicted was under the dominion of an abstract fury, experiencing no "lesion of understanding". Such a conception of mental alienation had profound implications for medical jurisprudence because the fundamental criterion of criminal responsibility was the actor's capacity to understand the nature of what he was doing. Pinel's formulation suggested that understanding could remain intact while the individual was carried away by some blind force, perhaps by a will no longer informed (or constrained) by conscious choice. Although he did not draw out the forensic implications of manie sans délire, nor specifically denominate his term as a form of partial insanity, the model of the mind's functioning which he envisioned would make more problematic the task of determining the actor's intent, since it now appeared that understanding and will might operate more or less independently from one another.

Pinel's student, Esquirol, continued the effort to refine traditional conceptions of mental pathology by bringing nineteenth-century disease classification into line with contemporary French psychology. ${ }^{34}$ The decline of humoralism in the eighteenth century meant that melancholia's long association with black bile appeared as so much anachronistic residue. In keeping with the emerging sensationalist psychology of the Enlightenment, melancholia was reconceptualized as an irritation or a disorder of sensitivity in which the mind became preoccupied with a single idea. According to Esquirol, however, melancholia's association with black bile was only one of its defects as a classification. Its connection with sadness or a general mournful disposition was too limiting a characterization of the emotional states which accompany preoccupation with an idea. To remedy both shortcomings, Esquirol

\footnotetext{
32 For Gall's views on criminal responsibility, "illusive liberty", and free agency, see The Weekly Medico-Chirurgical and Philosophical Magazine, 14 June 1823, no. 19, pp. 289-97; 21 June, no. 20, pp. 305-10; 5 July, no. 22, pp. 337-40; and 12 July, no. 23, pp. 353-7.

33 Although Cullen acknowledged that such cases existed, his own opinion was that "the limits between general and partial insanity cannot always be so exactly assigned". Stanley W. Jackson, "Melancholia and partial insanity', J. Hist. behav. Sci., 1983, 19: 173-84. See also William Cullen, Nosology: or a systematic arrangement of diseases, Edinburgh, C. Stewart, 1800.

${ }^{34}$ Jan Goldstein, Console and classify: the French psychiatric profession in the nineteenth century, Cambridge University Press, 1987; see especially pp. 245-57.
} 
proposed his own neologism, "monomania", which would combine the (former) melancholic's fixed concentration on an idea or set of ideas, with a lively and expansive disposition. ${ }^{35}$

According to G. E. Berrios, monomania was a version of the partial insanity concept ${ }^{36}$ except, of course, that it was a full-blown derangement as long as the afflicted's mind was turned to the delusion. Where Esquirol parted company with Arnold's notional delirium and Cullen's partial insanity, was in his contention that monomania could stem not only from a lesion of the intellect, but also independently from the emotions or the will. What he asserted was a fully emotional insanity, one in which the intellect was not suspended, but rather over-ridden. ${ }^{37}$ In délire partiel, for example, persons "perform acts and hold odd, strange and absurd conversations, which they regard as such, and for which they censure themselves". 38 The irresistibility of this state, according to Esquirol, was a "manifestation of a secondary disorder of the volitional faculty".

Disorders of the volitional faculty were further explored by Esquirol's student, Georget, who divided monomania into lesions of intelligence (delirium, a disturbance in the combination of ideas) and lesions of will ("perversion of natural penchants, affections, and passions"). But it was his classification monomanie homicide which brought the French alienists into direct collision with the legal community. The notion that there was a mental state which actually propelled its victims to commit murder was perceived as both ludicrous and dangerous, and was the occasion of a forceful denunciation of monomania by the lawyer Hannequin: "the need to murder to satisfy passions or perhaps a system is not an illness or insanity. The doctrine of monomania tries to excuse crime by crime itself". ${ }^{39}$ For the larger legal community, the domination of a single idea-Esquirol's criterion for monomania-had to be coupled with delirium if this state was to qualify as insanity. A man was not insane unless he "has lost either the consciousness of his own being or way of being, or of his social condition, or the relations of outside objects to himself and to each other". ${ }^{40}$

It was "emotional insanity" which was under attack. The two sides of the debate were clearly taken by those like Esquirol, who envisioned a complete separation of the human faculties of will, intelligence, and feeling-maintaining that any one of these could be independently affected by a lesion resulting in a state of partial insanity-

${ }^{35}$ Ibid., pp. 152-8.

${ }^{36} \mathrm{G}$. E. Berrios, 'Obsessional disorders during the nineteenth century: terminological and classificatory issues', in W. F. Bynum, R. Porter, and M. Shepherd (eds.), The anatomy of madness: essays in the history of psychiatry, vol. 1, People and ideas, London, Tavistock, 1985, pp. 166-87.

${ }^{37}$ Werlinder, op. cit., note 21 above.

38 J. E. D. Esquirol, Mental maladies, a treatise on insanity, transl. E. K. Hunt, Philadelphia, Lea \& Blanchard, 1845, p. 351.

${ }^{39}$ Raymond de Saussure 'The influence of the concept of monomania on French medico-legal psychiatry (from 1825 to 1840 )', J. Hist. Med., 1946, 1: 373. There were voices within the medical community which also protested the likely effects that concepts such as monomania would have at law. To these critics, "homicidal monomania" was (simply) "murderous fury" and they called for the punishment of those who committed crimes while in such state. "There is crime on the part of a madman when the means of carrying out the act have been weighed and carried out in order to satisfy a desire that is contrary to the eternal moral law. If insanity is to be made an exception, the law only intended it to be in cases where no motive for murder could be found." Ibid.

${ }^{40}$ Ibid., p. 377. 
and those members of the medical (and legal) profession who insisted that whatever the affective state of functioning, without a corresponding condition of delirium, the agitation did not amount to insanity. ${ }^{41}$ Although asylum registers reveal that as a diagnosis, monomania fell from psychiatric favour shortly after the mid-point of the nineteenth century, ${ }^{42}$ it must be admitted that the passions, long recognized but relegated to marginal significance, had finally made their influence felt in the conceptualization of insanity. ${ }^{43}$

The nature of the relationship between the emotions and insanity was also the subject of speculation for a group of medico-philosophical writers in Scotland, who rejected the more physiologically-based assumptions of English associationism in favour of a return to a conception of the mind as constituted by innate, inductive faculties. Members of the Common Sense School conceived of a mind endowed with its own capacities to respond to sensation and to employ these faculties to form combinations of ideas. ${ }^{44}$ Inherent faculties of attention, memory, imagination, and comparison actively sorted, arranged, and stored the ideas which constituted the basis for knowledge. The faculty of comparison was singled out by John Conolly in his 1830 treatise on insanity: "the madman concludes that what is only illusion is reality". When the faculty of comparison cannot be exerted, when the person cannot examine and revise his "morbid association, respecting the motives of friends or relatives" the mind is no longer sane. ${ }^{45}$ According to this asylum superintendent and author, the culprits responsible for the insanity are the passions and emotions which so excite the imagination that the mind is disturbed by "a direct impairment of the comparing power, and consequently, the judgment". ${ }^{46}$ With reason "dethroned", the will is no longer restrained by judgement and the afflicted is perforce driven madly by his passions: "it is only when the passion so impairs one or more faculties of the mind as to prevent the exercise of comparison, that the reason is overturned". 47

\footnotetext{
${ }^{41}$ According to Goldstein, Esquirol was also initially convinced that intellectual delirium attended monomania, but later changed his opinion due to pressures emanating from within his circle to present a united front to the legal community regarding the independence of a "lesion of the will" in Georget's monomanie homicide. Goldstein, op. cit., note 34 above, p. 174. Also see Esquirol's comments regarding monomania: "the understanding is more or less affected; were it not thus, the insane would permit themselves to be controlled by their understanding, and would discover that their views were false, and their actions unusual and strange", Esquirol, op. cit., note 38 above, p. 321.

${ }^{42}$ Goldstein, op. cit., note 34 above, p. 191. For an extended analysis of monomania's decline, see pp. 189-96. Further shortcomings of the monomania concept are described in Berrios, op. cit., note 36 above, pp. 170-1.

${ }^{43}$ Although Gall had referred to his psychological attributes as "determinate faculties", the affective component of the "organ of love of offspring", the "organ of vanity," "the organ of ambition", and the "disposition to murder" begged the question of insanity as primarily a matter of intellectual delirium. In fact, in declaring his differences with Locke's conception of insanity, Gall had cited Pinel's discovery that furiously insane persons frequently experienced no derangement of the intellectual faculties. Pinel's descriptions, Gall reported, revealed insane persons showing no symptoms of wandering with respect to memory, imagination, or judgement. The Weekly Medico-Chirurgical and Philosophical Magazine, 2 Aug. 1823 , no. 26 , pp. $18-21$; 19 July 1823 , no. 24 , p. 369.

${ }^{44}$ Hoeldtke, op. cit., note 11 above, pp. 55-63. See also G. P. Brooks, 'The faculty psychology of Thomas Reid', J. Hist. behav. Sci., 1976, 12: 65-77; and Frank M. Albrecht, 'A reappraisal of faculty psychology', ibid., 1970, 6: 36-40.

${ }_{45}$ John Conolly, An inquiry concerning the indications of insanity with suggestions for the better care of the insane, London, John Taylor, 1830, p. 155.

46 Ibid., p. 225.

${ }^{47}$ Ibid., p. 277.
} 
Where Conolly spoke of the will only after placing his attention squarely on the defective faculty of comparison, James Cowles Prichard sought to enlarge the inquiry into the pathology of mental processes by considering the emotions (or the passions) to be "another class of mental phenomena distinct in their nature from ideas". 48 Although he did not deny that derangement could lodge in a disordered exercise of intellectual faculties, he also believed that madness consisted in "a morbid perversion of the feelings, affections, and active powers, without any illusion or erroneous conviction impressed upon the understanding". 49 The moral character, the affections, the temper, the morbid feelings could themselves be deranged. By "moral insanity" Prichard signified,

the loss of voluntary power over the succession of ideas [which] is so great in a certain period of dementia that the individual affected is incapable by an effort of mind of carrying on the series of thoughts to the end of a sentence or proposition. He hears a question, apprehends sometimes its meaning, and attempts to answer; but before he has uttered the half of his reply, his mind becomes confused and bewildered, some accidental suggestion turns aside the current of his ideas, which are too loosely associated to remain, even in a short train, coherent: his expressions become consequently absurd and irrelevant. ${ }^{50}$

In this state of instinctive madness, the individual has not failed to understand the wrongfulness of his actions because he was "confused" or "deluded". Rather, "some ruling passion seems to have entire possession of the mind, and the hallucination is in harmony within it, and seems to have its origin in the entire excitement of the predominant feeling." 51 The impulsive nature of the will impels the person into motiveless, revolting criminal activity. Prichard's assertion that the act of the madman is for the most part without motive emphasized the non-rational, indeed self-destructive, component found in many cases of insane criminality. The inexplicable nature of some bizarre criminal activity-stealing unwanted items, killing a beloved infant-seemed to exemplify the tragic consequences of moral insanity. The lack of a motive-indeed the very want of any logical reason for the act-suggested a blind force that "neither reason nor sentiment determine" and which the will has no longer the power to control. ${ }^{52}$

\footnotetext{
48 James C. Prichard, A review of the doctrine of a vital principle as maintained by some writers on phrenology. With observations on physical and animal life, London, Sherwood, Gilbert \& Piper, 1829, p. 176.

${ }^{49}$ Idem, A treatise on insanity and other disorders affecting the mind, London, Sherwood, Gilbert \& Piper, 1835 , p. 12.

50 Ibid., p. 95.

51 James C. Prichard, On the different forms of insanity in relation to jurisprudence, designed for the use of persons concerned in legal questions regarding unsoundness of mind, 2nd ed., London Hippolyte Baillière, 1847 , p. 69.

52 Prichard apparently hoped to convey in the classification, moral insanity, a degree of awareness of one's actions without a corresponding exercise of the functions of comprehension and understanding. Moral insanity therefore consisted in the suspension of the mind's faculties, but not an absence of consciousness. It was the suspension of the former which theoretically rendered him irresponsible at law. It must be acknowledged that the nature of the afflicted's consciousness is difficult to comprehend: he does not "understand" why he is engaged in the activity, but he is not unmindful that he is carrying out some horrific deed either.
} 


\section{Joel Peter Eigen}

Prichard's attention to will makes explicit a change in the conception of partial insanity which had begun with the French school. As late as the early nineteenth century, Cullen could still characterize partial insanity as a false or mistaken judgement on one particular subject. A second meaning for partial insanity emerged with Pinel and Esquirol: a condition, variously referred to as manie sans délire or a "lesion of the will", in which the judgement was not directly affected. The fullest statement of this condition was to be found in monomania: an emotional insanity in which the intellect was over-ridden, but not itself deranged. As with the intellectualist conception of partial insanity, monomania narrowed the concept of delirium to derangement on one subject, but unlike the eighteenth- and early nineteenth-century associationist school, the French approach to circumscribed derangement included a spur to action. Monomaniacs, according to Esquirol, were not only deluded on one point, but exhibited heightened levels of excitation and even audacity. Georget had been even more predictive: persons afflicted with monomanie homicide were impelled to translate a preoccupation with the idea of murder into action. ${ }^{53}$ Although members of the Scottish Common Sense school were not as specific regarding the ineluctable consquences of moral insanity, the will and its perversion at the hands of inflamed passion was much more in focus than in the previous century. The thrust of the French school of médecin mentale and Common Sense philosophy was therefore to remove the will from its normative subjugation by the intellect and to endow it, along with the emotions, with a life (and destructive force) of its own. Monomania could be intellectual, affective, or instinctual. Moral insanity could over-ride the intellect while the individual was carried away by perverted feelings.

The narrowing of insanity to signify partial states of derangement thus fragmented the unity of the actor's mental integrity: will, intellect, or emotion could each suffer discrete impairment. Or rather, the afflicted might be clinically, or philosophically, so described. Whether he could be legally deranged when his intellect was left more or less intact had yet to be negotiated with the court.

\section{DELUSION IN THE COURTROOM}

In 1830, Gilbert McMurdo, Surgeon of Newgate, concluded his testimony with the following words: "We consider delusions a very common test of insanity; and that of a man's family conspiring against him is one of the most common, and what we are apt to regard as a test of an unsound state of mind." 54 The significance of these remarks extends beyond the fact that they were offered in open court by a medical man in the employ of Newgate Gaol. While medical witnesses had been giving evidence in insanity trials since 1760, McMurdo was the first to speak of a "test"; the presence of a condition sufficient to find insanity. His testimony, and that of half the medical witnesses who appeared at the Old Bailey between 1825 and 1843 to speak on behalf of the prisoner's plea of insanity - and provided grounds for their inferencedescribed a conscious, purposeful act generated by a false belief: in other words, a

\footnotetext{
53 de Saussure, op. cit., note 39 above, pp. 370-2. For a discussion of the debate surrounding monomanie homicide, see Goldstein, op. cit., note 37 above, pp. 170-8.

${ }^{54}$ OBSP, 1830, First Session, p. 91.
} 
reasoning mania. Although clinicians and authors of medical texts beginning with Cullen and Pinel had made the transition from total to partial insanity, the long-standing rejection of partial insanity on the part of English criminal jurisprudence presaged a much more sceptical audience when medical witnesses proffered their construction of a limited insanity in court. And this scepticism did not wane with the years. McMurdo's summary comments in 1830 established no more of an obvious precedent for delusion as the "test" of insanity than had Thomas Erskine's articulate and innovative use of delusion in the defence of James Hadfield 30 years earlier. Something more than simple scepticism on the part of the court kept delusion, monomania, and moral insanity from establishing themselves as the "test" of insanity.

The protean character of madness itself meant that insanity, and consequently the limits of criminal responsibility, had to be defined anew at every trial. Although the mental state of the prisoner was of obvious relevance to the trial, it was not the mental state per se which the jurors had to divine. Juries were asked to discover if the prisoner had retained an ability to "know what he was about", or to distinguish right from wrong, not to detect the presence of delusion, lunacy or melancholia. Also, as late as 1785 , judicial instructions reminded the court that "it must be a total derangement of the mind ... however it may approach to that degree of disorder ... yet unless it goes that length, it does not amount to a justification". ${ }^{55}$ Medical witnesses who stopped short of global delirium in their characterization of the prisoner's mental state therefore faced a formidable task: how to explain that the defendant could be conscious of his actions and yet fail to understand their moral wrongfulness.

To reconcile this seeming contradiction, medical witnesses alluded to images of mental functioning which challenged the notion of the mind as an integrated unit. They asked jurors to consider a form of insanity which consisted of a circumscribed, limited derangement, referred to as either "delusion" or "monomania". Partial insanity in the second quarter of the nineteenth century was not derangement by degrees (historic melancholia) but rather a capacity for the mind to house both rationality and madness simultaneously. Evidence suggesting the prisoner's clear reasoning on one particular subject in no way precluded the possibility of deep derangement in another area of his thinking. Nor was the forensic witnesses' use of a limited insanity similar to the traditional notion of lunacy, in which delirium and lucidity alternated with one another. Instead, reasoning and madness could be manifest at the same moment, a condition Gall had referred to as partial alienation. ${ }^{56}$ In their descriptions of prisoners in such a mental condition, medical witnesses challenged the court's practice of calling an insanity plea into question by asking witnesses to recount events on the day of the crime which evinced thought or planning. ${ }^{57}$ Contrivance could now be redefined as (mono)maniacal pursuit, rather than as cleverness that betokened rationality, and hence, intention.

\footnotetext{
55 OBSP, 1785, Sixth Session, p. 875.

${ }^{56}$ For Gall's views on partial alienation, see The Weekly Medico-Chirurgical Philosophical Magazine, no. 25,26 July 1823, pp. 2-3; on intermittent alienations, see 19 July 1823, no. 24, p. 369.

${ }^{57}$ For example, see Mansfield's comments at the trial of James Bellingham for the murder of Spencer Perceval, in Eigen, op. cit., note 2 above, pp. 46-7.
} 
Testifying in 1833, the physician and author David Uwins explained to the court why the prisoner's obvious planning and execution of a forgery did not alter his opinion that she was, in fact, insane:

\begin{abstract}
Among my patients at the Institution, they have gone through the process of reasoning for the object they have in desire, as a sane person would-the act itself, I should not call an act of insanity, but should conclude that an individual, being insane, could perform that act; there may be considerable imbecility of mind, and yet the process of reasoning exist-I conceive it possible for an individual to act as the prisoner did with respect to this cheque, without knowing the degree of responsibility under which she herself must stand in reference to it. ${ }^{58}$
\end{abstract}

Asked specifically by the court: "Do you conceive all this stratagem might be employed without a consciousness of there being anything wrong in it", Uwins replied: "I conceive it possible, having seen several instances where the object has been of less importance". All the prisoner's planning, all the contrivance displayed in "obtaining her object" did not encompass her appreciating the "responsibility under which she herself must stand with reference to it". To underline this last point, Uwins stated, "I don't think she was in a state to distinguish right from wrong at the time of this affair". The apothecary Thomas Halifax, who followed him into the witness box, expounded the question of a limited insanity:

I consider a disorder of some intellectual faculty a symptom of insanity, monomania is insanity, relative to one particular subject, distinguished from a disordered intellect relative to all affairs ... it is known that insane persons have pursued an object with a degree of cunning which belongs to very few except the most exalted talents. ${ }^{59}$

Conscious of her actions--indeed, shrewd in accomplishing her ends- the prisoner was nonetheless, jurors learned, not "in a state to distinguish right from wrong at the time of this affair". What inferences about the mind were they to draw from such a description? First, consciousness and purposeful action were apparently not eclipsed by madness. The single-minded pursuit of an objective might seem like rationality, but it was an idiosyncratic form of reason because it was disconnected from related faculties of judgement and understanding: the exercise of reason was restricted to one subject only. A second implication followed. Understanding the sequence of steps necessary to accomplish one's ends need not necessarily extend to appreciating the moral context in which one's actions are pursued. Uwins left no doubt that, though perfectly capable of knowing how to execute a plan, the prisoner was not capable of knowing the (criminal) responsibility to which she exposed herself. Insanity so described had little in common with "wild beast" delirium familiar to the early eighteenth century. This defendant, a functioning, conscious, purposeful actor, was yet described by the asylum physician as irresponsible due to her monomaniacal preoccupation.

The frequency with which medical witnesses in the nineteenth century invoked delusion, the unselfconscious manner in which family members commented upon it,

${ }^{58}$ OBSP, 1833, Seventh Session, p. 733.

59 Ibid., p. 734. 
and the courts asked about it, suggests a level of familiarity with a word which, only a short time before, was rarely if ever spoken in criminal court. Jurors at the Old Bailey were not given a medical explanation of restricted impairment in associationist, phrenological, or faculty-psychology language. Rather, physicians, surgeons, and apothecaries employed everyday language and common-sense images to depict the extreme behavioural variability that resulted when a person's mind "laboured" under some delusion.

What was uncommon about their testimony was how it called into question assumptions about the mind's ability either to integrate intended action with moral consequence, or to maintain a consistent state of consciousness, particularly an awareness of what one was "about". In the following extract, delirium was said to follow the mentioning of a subject upon which the afflicted individual was preoccupied:

when he was not in this state of delirium I should say he was generally capable of knowing right from wrong, and conducting his own affairs ... when he became calm he never spoke of these acts, nor allow himself to be spoken to on it . . ${ }^{60}$

But, as the physician explained, when the prisoner's mind was unsettled, he was "unconscious of what was passing". Of what use was the criterion "knowing what one was about" if the mind was subject to states of consciousness which at times left the person oblivious to what was immediately transpiring but at other times permitted active circumnavigation around delirious shoals? Medical witnesses might affirm that a prisoner could indeed distinguish right from wrong, yet still stand not accountable for his or her acts because of an unsound mind brought on by a "state of hysterical insensibility", once the delusion was touched upon.

In sum, although the capacity to distinguish right from wrong or to know what one was "about" may have historically functioned to separate the totally insane from those who suffered only "derangement by degrees", the utility of these criteria became increasingly doubtful when medical witnesses proffered a view of the mind's functioning in which the capacity to distinguish right from wrong was subject-just as all "knowing" functions were subject - to the overall state of well-being. There simply was no general faculty of "knowing right from wrong", or "knowing what one was about" which had the power to correct a delusion and by so doing alert the afflicted that the action which flowed from the false belief was morally transgressive. The limited insanity which medical witnesses introduced into courtroom testimony took one of two forms: a reasoning mania (symbolized by contrivance or monomanical pursuit) or an episodic descent into deep distraction (occasionally referred to as delirium) when the subject of profound anxiety was touched upon. In both cases, delusion or monomania signified the presence of an area of functioning in which any customary capacity to distinguish right from wrong, or to "know what one was about" did not intrude. The following table reveals the frequency with which "delusion" and "monomania" were mentioned by 34 medical witnesses who supplied a reason (or reasons) for their insanity diagnosis.

${ }^{60}$ OBSP, 1842-43, Twelfth Session, p. 1005-6. 
Terms employed to support the inference of insanity, 1825-1843

Term

Frequency

Delusion

Monomania

3

Brain fever, Organic brain disease $\quad 2$

Derangement: about the eyes, melancholic 2

Eccentric, delirious 2

Conversation: flighty, incoherent 2

Epilepsy 1

Bowel complaint 1

Termination of blood to head, in consequence of an epileptic fit 1

Brain injury in battle 1

"Approached" an imbecile, idiocy 1

A singular inability as regards the affections 1

State of lunacy, delirious 1

Puerperal mania 1

Head was "affected" 1

"Peculiar look": quivering of lips, face effused with blood 1

Contrivance

Perversion of the moral feeling 1

Lesion of the will, moral insanity 1

Out of the pale of self control 1

Insensibility 1

Included in the above array are several references to organic or physicalist "causes" of insanity which medical witnesses sometimes used in situating delusion or monomania in an overall picture of mental functioning. The following testimony extracts suggest that the eighteenth-century tendency to associate mental disturbance with damaged nerve endings or faulty cerebral circuitry had, by the second quarter of the nineteenth century, extended to include a consideration of the role of general somatic disturbance in the derangement of mental faculties. In 1827, the surgeon $\mathrm{Mr}$ Houghton responded to a question regarding whether delusions were the test of insanity, with the following:

Certainly; I have heard the woman's account of his bowel complaint; its being attended with bleeding would be very beneficial to his state of mind; it would improve it, and on his getting stronger, the delusion would be more likely to return. ${ }^{61}$

One hears in Mr Houghton's words a compelling echo of the centuries-earlier remedy of inducing haemorrhoidal bleeding as a measure to relieve melancholia-an affliction often attended with delusion. ${ }^{62}$ Although the surgeon did not explain what effect bleeding would necessarily have on the intensity of the prisoner's delusion, his comments resonated with cultural as well as medical assumptions about the easy traffic between physical changes and brain function; in this case, the strength of a

${ }^{61}$ OBSP, 1827, Seventh Session, p. 628.

62 Jackson, op. cit., note 16 above, p. 31. 
false belief. The association of blood flow and delusion was made a year later by another surgeon, John Fenner, who, when asked to speak about the relation between the prisoner's fits and his derangement, responded thus:

I was called to attend the prisoner in February 1827, and found him suffering from a violent hemorrhage from the nose, in consequence of a termination of blood to the head, which was very probably caused by great excitement of the mind . .63

The witness's comments reveal that the traffic between the mind and pathological physical change could indeed be two-way. The implication of his words-as of Houghton's as well-was that the intensity of the delusions was associated with physical changes which, in some unspecified way, had affected brain function.

In 1840, jurors learned of a therapeutic connection between delusions and blood flow during the trial of a man indicted for the attempted murder of his wife. The prisoner, a medical man himself, endeavoured to persuade the court of his lack of "intent to do [his wife] any serious injury or any bodily harm" because, he explained, "I most decidedly say it must be a delusion altogether". After the jury learned that the prisoner believed his wife to be "poisoning him by degrees ... putting arsenic into his lips while he was sleeping ...", they next heard from a medical witness who was asked by the court: "What was his delusion?" Samuel Taylor responded, "He thought his disease was more important than it was-he considered he should die and had sleepless nights". The prisoner apparently feared that the jury would doubt the extent of his distress and asked the witness: "Did you not sometimes see me three times in the course of a day?" The surgeon-apothecary replied: "I have . . . bled you very largely one morning, by desire of Dr. Scudamore-you had blisters applied to the nape of your neck many times". Dr Scudamore next took the stand, asserting that he believed the prisoner to have been "in a state of monomania, in which case he would very readily have his ideas perverted, and take up with any delusions that might engage his thoughts and feelings". He then explained his choice of treatment:

I considered the indication of the brain, at my first visit, to be of an inflammatory nature, and with which I thought the heart sympathised-I judged it expedient and necessary to direct the removal of blood [addressing the prisoner:]-although you never recovered, you got into a better state of health-the medicines were administered on the same view of the disease as that on which I directed the abstraction of blood . . . except as related to your disorder, I did not find any irregularity of mind. ${ }^{64}$

Aside from the singular drama supplied by a medical witness explaining treatment protocol to a patient on trial for the near-fatal assault on his wife, one also sees a further affirmation of the association drawn between changes in blood flow-to relieve the brain's "inflammatory nature"-and the resulting "better state of health", presumably a diminution in the intensity of his delusion.

${ }^{63}$ OBSP, 1828, Sixth Session, p. 624.

${ }^{64}$ OBSP, 1840-41, First Session, p. 25. 
The willingness of medical witnesses to situate mental pathology in somatic disturbance did not extend to invoking the most widely known conceptual scheme for conjoining physiology and behaviour: phrenology. The contemporary phrenological literature, on the other hand, invoked criminal behaviour time and time again to support its most fundamental tenet: the independence of psychological faculties. ${ }^{65}$ Such a depiction of the mind's functioning enabled phrenologists to account for outrageous acts by seemingly rational people. That an insane person could execute a plan - contrive a forgery?-with cunning and methodological sophistication, need hardly remain a mystery. It was the "organ of covetousness" or the "organ of cunning" which was implicated as the medium responsible for an insane act committed by an otherwise law-abiding person. Given the currency of phrenology in the second quarter of the nineteenth century in both lay and scientific circles-indeed the largest group of professionals comprising the membership rolls in the first half of the nineteenth century were medical practitioners ${ }^{66}$-one is struck by the absence of phrenological images in the years which witnessed the tremendous growth of expert testimony in insanity trials.

Although there is no reason to suspect that most witnesses necessarily subscribed to phrenological principles, there was at least one prominent phrenologist who made an appearance at the Old Bailey. David Uwins, whose testimony in a forgery trial was discussed earlier, wrote several books on brain disorders and contributed to magazine articles and encyclopaedia entries on the subject of phrenology. His medical writing may have been grounded in cerebral matter, but not his courtroom testimony. The strength of phrenology, he had written,

consists in its having discarded imaginative reasoning, and sent it back to its proper province; and in having taught us to regard everything that concerns the living principle as futile and unsubstantial, beyond what can be made out upon the common principles of physics. ${ }^{67}$

Yet in his court appearance in 1833, these sentiments are not expressed. He testified instead to the prisoner's cunning (but not about her organ of cunning) and to the fact that, though her process of reasoning might exist, there remained considerable

${ }^{65}$ Infanticide, for example, was often explained with reference to the "organ of parental and filial love". See C. W. Hufeland, Some account of Dr. Gall's new theory of physiognomy, London, Longman, Hurst, Rees, \& Orme, 1807. A murder in 1819, attributed to the unfortunate felon's enlarged "organ of destructiveness", is described in George and Andrew Coombe, On the functions of the cerebellum by Drs. Gall, Vimont, and Broussais, Edinburgh, Machlachlan \& Stewart, 1838, pp. 162-7. Further examples of the uses of crime and other desperate acts to support phrenological principles may be found in Charles $\mathrm{A}$. Blöde, Dr. F. J. Gall's system of the functions of the brain, 1807; Andrew Coombe, Observations on the mental derangement being an application of the principles of phrenology to the elucidation of the causes, symptoms, nature and treatment of insanity, Boston, Marsh, Cape \& Lyon, 1834; and Forbes Winslow, The principles of phrenology as applied to the elucidation and cure of insanity, London, S. Highley, 1832. For a discussion of the specific importance of the evidence of monomania to the arguments of phrenology, see Roger Cooter, 'Phrenology and British alienists, ca. 1825-1845', in Andrew Scull (ed.), Madhouses, mad-doctors, and madmen: the social history of psychiatry in the Victorian Era, Philadelphia, University of Pennsylvania Press, 1981, pp. 58-104.

66 Cooter, op. cit., note 29 above, p. 93.

${ }^{67}$ David Uwins, A treatise on the disorders of the brain and nervous system which are usually considered and are called mental, London, Renshaw \& Rush, 1833, p. 15. 
imbecility of mind. No attempt was made to situate her imbecility of mind in damaged or pathological development of particular organs of the brain.

One might suspect that although phrenology enjoyed considerable popularity in both lay and at least some scientific circles, the language it employed- "organs" of determinate faculties, for example-was too unfamiliar, too far removed from the discourse of the layman, to be taken seriously by the court. While medical witnesses did introduce physicalist concepts into their discussion of delusion and monomania, the materialism inherent in an "organ of destructiveness" threatened the substitution of an unproven, and to some minds far-fetched, "science of character" for the more culturally intelligible concepts of intent and "knowledge of what one was about". The importance of sensitivity to the forum in which they were testifying was not lost on medical writers of the early decades of the nineteenth century, who cautioned their colleagues to keep their language intelligible to the non-specialist. Accordingly, analysis of their courtroom testimony in the second quarter of the century reveals that medical witnesses were very careful how they spoke about will and the capacity of human choice. Only in the fifth decade of the century did physicians and surgeons actually mention the issue of self control. When they did, their imagery was initially devoid of Prichard's notions of moral insanity. Speaking in 1840, a medical witness averred:

I have seen him from time to time in states when I believe he was out of the pale of self control-I really cannot say whether that arose from an obstinate, perverse or wicked disposition, or from his mind being disordered ... I have seen him at times so excited that he is not answerable for his actions-indeed has no control over himself . . 68

The most articulate pairing of delusion with loss of self-control was made only at the very end of the period under review, during the trial of Daniel McNaughtan. Nine physicians and surgeons testified in the celebrated trial of Sir Robert Peel's would-be assassin, many addressing their remarks to the force inherent in the delusion itself which led McNaughtan to the offence. The McNaughtan jury was told that the prisoner's act "flowed from those delusions . . . he was not under the ordinary restraint by which persons in general are bound in their conduct; his moral liberty was destroyed". ${ }^{69}$ Asked directly by the court if the prisoner was "capable of exercising self control and resisting the impulse to which he yielded" one medical witness replied that any act which flowed from his delusion was an irresistible one: "the impulse was so strong that nothing. short of a physical impossibility, would prevent him from performing any act which his delusion might impel him to do". 70 Added another physician: "I mean the black spot on his mind, regarding the delusion . . . the commission of that act is placed beyond his moral control". ${ }^{71}$

"Delusion" had progressed from a disturbance of thought, and false belief, to a force which removed self-determination from the sphere of one's control, and this was

${ }^{68} O B S P, 1842-43$, Twelfth Session, pp. 1006-7.

${ }^{69} O B S P, 1843$, Fifth Session, p. 760.

70 Ibid., p. 761 .

71 Ibid., p. 762. 
fast becoming the Victorian view of mental disorder. As Michael Clarke has written, the "Ego or psychical person lost its power of self-determination and regressed to 'lower', more automatic levels of psychological functioning, the mind becoming increasingly absorbed either by delusive constructions based on internal, 'subjective' sensations (as in hysteria and hypochondriasis) or by externally suggested dominant ideas (as in hypnosis)". ${ }^{72}$ Behaviour now revealed the force of dominant ideas and instincts; rational inquiry and interpretation were closed off as conduct became more impulsive, automatic, irresponsible.

Although medical witnesses certainly found their clearest voice regarding delusion and compulsion in the McNaughtan trial, testimony found in the $O B S P$ leading up to 1843 records physicians and surgeons speaking in terms of a mind "labouring under a delusion", disposed to delusion [with] a perversion of the moral feeling", and "out of the pale of self control". Jurors and others at the Old Bailey learned of the autonomous force of the passions, the morbid sentiments, and the resulting monomaniacal pursuit of an objective which had impelled the prisoner into criminal activity. Could a mind preoccupied with threatening and compelling sensation be capable of applying customarily understood norms of morality to the action it contemplated? Medical witnesses who spoke in terms of the prisoner's "antecedent delusion [leading] to one particular offence or another", and the need to "take into account the exceeding cunning connected with mental alienation, especially when there is intention to accomplish an object" challenged traditional criteria for assessing intent, which had relied exclusively on the "knowing" faculties. The integration of intellectual faculties could easily be fragmented by the will, which had the power to "modify the association among ideas ... and ... the results to which the important principles of association give rise". ${ }^{73}$

It appears, therefore, that by the mid-nineteenth century partial insanity had extended beyond the associationist tenets of a Cullen or an Arnold, who restricted its meaning to a false judgement on a particular subject. Reflected in medical testimony in the second quarter of the century were the ideas of Esquirol, Georget, and Prichard, whose views of limited derangement revealed the separate force of the perverted will-with or without intellectual confusion. This was a novel sort of derangement: self-control-not intellectual coherence-was the primary loss. The intellect, heretofore the "higher" power which customarily subdued the "rabble" in the psyche, could now be over-ridden in the wake of a passionate, wilful, pursuit of an objective. More frightening still, the intellect might retain its lucidity even as the will, diseased in its own right, impelled the actor into criminality.

Perhaps the most graphic rendering of the association of delusion with compulsion was supplied by a prisoner in 1830 when he uttered his Defence at the end of the trial. James Sisk was indicted for having fired a pistol at an attendant in the House of Lords. The prisoner had arrived at the Lords to see the Duke of Wellington to report on the commission he had received from God. As the defendant testified:

\footnotetext{
72 Michael Clark, 'The rejection of psychological approaches to mental disorder in late nineteenth-century British psychiatry’ in Scull (ed.), op. cit., note 65 above, p. 274.

${ }^{73}$ Prichard, op. cit., note 49 above, p. 94.
} 
I did what I was commissioned to do by God Almighty . . . it is ten years since God gave me the commission, I went to Baltimore to get a commission-but by the providence of God I did not succeed ... I went to the city, and gave myself out to be a prophet to warn them all of the approaching destruction; I came home to this country - it wore off, but it would not let me be quiet; I came to London a few months ago ... . and I pledged to Almighty God that I would then go and preach to the people if he would spare me ...74

Apparently, the defendant was waiting outside the House of Lords to tell the Duke of Wellington of his progress in encouraging Londoners to repent, when the unfortunate guard tried to remove him, and was fired upon. Clearly, the assault on the guard was not directly dictated by the delusion, but the jury acquitted the defendant, doubtless taking the surgeon, Gilbert McMurdo's, words to heart: "We consider delusions a very common test of insanity". 75

\section{PARTIAL INSANITY IN LEGAL AND CULTURAL CONTEXT}

In addition to providing historians of medicine with evidence of the diffusion of clinical concepts of partial insanity into the courtroom setting, trial narratives found in the $O B S P$ also offer clues regarding how inhabitants of early modern England conceived of mental processes, particularly the working of the distracted mind. As cited earlier, lay concurrence in the medical interpretation of lunacy, discernible in the profusion of non compos mentis findings recorded in suicide inquests in the late seventeenth century, provided Michael MacDonald with compelling evidence of the increasing secularization of a disordered condition which, for centuries, had been consigned to supernatural forces. In like manner, the proclivity of jurors to entertain the legal merits of an insanity plea raised by prisoners who understood, at a certain level, what they were about-and who may have customarily possessed a general capacity to distinguish right from wrong - suggests a lay willingness to move beyond an exclusively intellectualist conception of the mind to a consideration of the potency of will and emotion in human, and particularly criminal, behaviour.

The medical witnesses' achievement was not the mystification of jurors with esoteric jargon, or the redefinition of madness in exclusively organic terminology. Rather, expert testimony in the second quarter of the nineteenth century skilfully employed common-sense imagery and familiar terms to question the court's longstanding criterion, which had functioned to restrict the scope of insanity acquittals. That only those totally incapable of distinguishing right from wrong could be said to lack the will to harm relied on the notion of the natural subjugation of the will to the intellect. During the second quarter of the nineteenth century, jurors, court bystanders, and readers of the $O B S P$ alike learned that the intellect could be overridden in the wake of a passionate pursuit of an object. The passions could, by themselves and with no accompanying "error in judgment", compel the actor to commit a crime. Though the prospect of such impulsive behaviour might have seemed frightening, one notes the temperate language English medical men used in suggesting

${ }^{74}$ OBSP, 1830, First Session, p. 90.

${ }^{75}$ Ibid., p. 91. 


\section{Joel Peter Eigen}

the limits of the "knowing" faculties. There is mention of monomania, but not homicidal monomania. A phrenologist speaks of cunning, but not an organ of cunning. Rather, medical testimony conveyed the image of a delusion or a state of monomania removing the capacity for self-control once the mind became "unsettled". One experienced release from the "ordinary restraint by which individuals in general are bound in their conduct". "Delusion", the term most frequently invoked by medical witnesses in the early nineteenth century, conveyed a "suspension of the controlling will". 76

The foregoing is not meant to imply that documenting a delusion was sufficient proof, or an indisputable "test" of insanity. Although delusions were good evidence of madness, Roger Smith has correctly asserted that the misperception had to be of a certain quality to answer the law's concern, namely "did [the prisoner] know that he was committing an offence against the laws of God and nature?"77 It was precisely the faculty of knowing which medical witnesses questioned when they described the state of the intellect once a person's will was seized by preoccupation. With all thought concentrated on the delusive fear or monomaniacal idea, what was the likelihood that a general knowledge of the difference between right and wrong, or "knowing what one was about" might actually intrude upon an idée fixe? If the afflicted could not apply reason to correct the delusion, how could he or she be expected to apply standards of right and wrong to acts compelled by the false belief? The testimony of the medical witnesses, and the subsequent acquittal of most of these defendants, strongly suggest that jurors answered the question regarding the prisoner's knowledge about the illegality of their actions by considering the degree of compulsion attendant to the false belief. When jurors heard such statements as, "it would not let me be quiet" and "something came over me" and "his delusion leads to one particular offence or another", the utility of the centuries-old criterion of knowing right from wrong for assessing intent was directly called into question.

These prisoners were not suffering from a cognitive failure or a moral lapse. Their own words, and those of medical witnesses, vividly illustrate a state of delirium in which the will was released to do delusion's bidding. Thus the ship's captain acted only as he could, to save himself from his tormentor, the owner of the shipping lines. His inability to recognize the error in his thinking did not affect his ability to command the ship. Yet once the name of his supposed nemesis was uttered, his odd - not to say burlesque - antics marked him as a man "without choice". Does anyone choose to dance on broken glass? His inability to exercise moral choice under such a state of mental confusion was doubtless the critical consideration. When another prisoner, who passionately believed that his brother was plotting to throw him into a boiling cauldron, proceeded to assault his sibling, the jury must have considered that this unfortunate, deluded man could not have chosen to do otherwise. Similarly, would an individual who believed himself to be sent by God with a heavenly commission, shrink from attacking a guard who actively prevented him from completing his divinely-ordered task?

\footnotetext{
${ }^{76}$ For a discussion of the nineteenth-century conception of the suspension of the controlling will, see Smith, op. cit., note 2 above, pp. 90-6. See also Hoeldtke, op. cit. note 11 above, p. 58.

${ }^{77}$ Smith, op. cit., note 2 above, pp. 94-5.
} 
The element of compulsion alluded to in the above cases is of paramount significance for the question of culpability because, as mentioned earlier, without choice - without the will to inflict harm - the individual cannot be said to have acted intentionally. In the eighteenth century, the question of intent was answered predominantly by considering the prisoner's understanding, his knowledge of what he was about, and his appreciation of the consequences of his actions. Insanity was a matter of impaired (or totally absent) reason. In their acceptance of "reasoning" madness, jurors in the nineteenth century redefined legally-relevant mental derangement to include a variety of states of being in which the intellect remained more or less intact, though temporarily suspended or over-ridden.

Although new to the court, the notion that the human mind could perform purposive acts which were nonetheless "unattended with consciousness" was gaining increasing popular acceptance. ${ }^{78}$ Activities such as respiration and pulse, dreaming and sleep-walking, exhibited forms of human action in which the individual's conscious, intentional decision seemed to be absent. The inclusion of moral insanity, delusion, and monomania into the category of states of consciousness in which reason was either temporarily suspended or over-ridden did not make insanity "just like sanity" but it did serve to normalize the crimes of the mad. The acquittal of most of the defendants in whose trials delusion or monomania was raised suggests the jurors' acceptance of a new, and perhaps prominent role for the agency of will and emotion. Although it is difficult to know how much weight to attach to the influence of medical testimony in the refinement of madness from intellectual error to compulsion to act, it seems clear that the concept of partial insanity drew the mad and the sane into much closer proximity. Might the juror have recognized in the partially deranged not only the similarity of states of consciousness in which reason failed, but a further resemblance in the potency of emotions not altogether restrainable by the intellect or the customary will? Might he have recognized in the mad the presence of hidden, treacherous forces which could lead any reasonable person into unintentional criminality?

${ }^{78}$ Porter, op. cit., note 14 above, pp. $180-1$. 